\title{
Epidemics and outbreaks of peripheral nervous system disorders: I. infectious and immune-mediated causes
}

\author{
Stéphane Mathis ${ }^{1}(\mathbb{1}) \cdot$ Antoine Soulages $^{1} \cdot$ Gwendal Le Masson $^{1,2,3} \cdot$ Jean-Michel Vallat $^{4}$
}

Received: 21 August 2020 / Revised: 28 August 2020 / Accepted: 2 September 2020 / Published online: 10 September 2020

(c) Springer-Verlag GmbH Germany, part of Springer Nature 2020

\begin{abstract}
The history of mankind is marked by numerous epidemics, some of which involved diseases of the peripheral nervous system, either infectious or otherwise. We describe here the three main infectious causes of epidemics that affect the peripheral nervous system: leprosy, poliomyelitis and diphtheria. We then discuss the main epidemics of immune-mediated origin.
\end{abstract}

Keywords Poliomyelitis $\cdot$ Diphtheria $\cdot$ Leprosy $\cdot$ Guillain-Barré syndrome $\cdot$ HIV $\cdot$ Lyme

$\begin{array}{ll}\text { Abbreviations } & \\ \text { AIDS } & \text { Acquired immunodeficiency syndrome } \\ \text { AMAN } & \text { Acute motor axonal neuropathy } \\ \text { AMSAN } & \begin{array}{l}\text { Acute motor and sensory axonal } \\ \text { neuropathy }\end{array} \\ \text { ART } & \text { Antiretroviral therapy } \\ \text { BB } & \text { Borrelia burgdorferi } \\ \text { CD4 } & \text { Cluster of differentiation } 4 \\ \text { CHIVKV } & \text { Chikungunya virus } \\ \text { COVID-19 } & \text { Coronavirus disease 2019 } \\ \text { CSF } & \text { Cerebrospinal fluid } \\ \text { DENV } & \text { Dengue virus } \\ \text { DTP } & \text { Diphtheria-tetanus-pertussis } \\ \text { GBS } & \text { Guillain-Barré syndrome } \\ \text { GM1 } & \text { Mono-sialotetrahexosyl-ganglioside } \\ \text { H1N1 } & \text { Haemagglutinin type-1 and neuraminidase } \\ & \text { type-1 } \\ \text { H1N1-pdm09 } & \text { Pandemic H1N1/09 virus (2019) } \\ \text { HIV } & \text { Human immunodeficiency virus }\end{array}$

Stéphane Mathis

Stephane.mathis@chu-bordeaux.fr

1 Department of Neurology, Nerve-Muscle Unit, CHU Bordeaux (Pellegrin University Hospital), Place Amélie Raba-Léon, 33076 Bordeaux, France

2 University of Bordeaux, U1215, 33000 Bordeaux, France

3 INSERM, Neurocentre Magendie, 'Physiopathologie de La Plasticité Neuronale', U1215, 33000 Bordeaux, France

4 Department of Neurology, National Reference Center for 'Rare Peripheral Neuropathies', University Hospital, 2 Avenue Martin Luther King, 87042 Limoges, France

$\begin{array}{ll}\text { IRIS } & \begin{array}{l}\text { Immune reconstitution inflammatory } \\ \text { syndromes }\end{array} \\ \text { LE } & \text { Lethargic encephalitis } \\ \text { ML } & \text { Mycobacterium leprae } \\ \text { MT } & \text { Mycobacterium tuberculosis } \\ \text { PCR } & \text { Polymerase chain reaction } \\ \text { PFEE } & \text { Peripheral form of epidemic encephalitis } \\ \text { PN } & \text { Peripheral neuropathy } \\ \text { PNS } & \text { Peripheral nervous system } \\ \text { polio } & \text { Poliomyelitis } \\ \text { RNA } & \text { Ribonucleic acid } \\ \text { SIV } & \text { Simian immunodeficiency virus } \\ \text { VAPP } & \text { Vaccine-associated paralytic polio } \\ \text { WHO } & \text { World Health Organization } \\ \text { ZIKV } & \text { Zika virus }\end{array}$

\section{Introduction}

The history of civilizations has been punctuated by a number of disease outbreaks that have decimated large proportions of the human population, greatly altering the structure and dynamics of societies, the recent coronavirus (COVID-19) pandemic being a new example of this constant threat to mankind. Since ancient times, the spread of such diseases was believed to be due to demons, gods or comets, before the theory of a noxious property of the air originating from rotting organic matter (miasmas) was advanced. Since the fourteenth century, the concept of 'quarantine' represents the cornerstone of a coordinated disease-control strategy. This term was first introduced in Ragusa (Dubrovnik, Croatia) in 1377 (then in the Venetian Republic). They experienced 
plague and leprosy and officially issued a 30-day isolation period for ships ("trentina"); a 40 day-period ("quaranta") was also applied to land travelers and adopted as an obligatory means of separating persons, animals, and goods that may have been exposed to a contagious disease [1].

With scientific advances, microorganisms were finally recognized as potential causes, but some outbreaks were also associated with non-infectious agents (toxic, nutritional, etc.). Neurological manifestations were observed after many outbreaks, affecting the central (syphilis, etc.) or the peripheral nervous system (PNS), so we propose to relate the history of the main human outbreaks (infectious or not) involving the PNS over the ages. In this paper, we deal with the 'big three' infectious disease outbreaks mainly involving the PNS (poliomyelitis, leprosy and diphtheria), with a second part focusing on epidemics of post-infectious (immune-mediated) peripheral neuropathy (PN).

\section{The infectious causes}

\section{Leprosy}

Leprosy (Hansen's disease) is a chronic, slowly progressing infectious disease for which a person-to-person transmission via nasal droplets is believed to be involved, although not fully proven. The main reservoir being humans, the 2-12 year incubation period represents a serious problem because of the absence of reliable tools to diagnose subclinical infection [2]. Leprosy is caused by the invasion of some body tissues by Mycobacterium leprae (ML), an obligate intracellular organism with a predilection to replicate in macrophages, endothelial cells, and Schwann cells. The hallmark of leprosy is the chronic granulomatous inflammation of skin and peripheral nerves, the cell-mediated immune response to infection explaining the variants of the disease: tuberculoid (good immune response; few focal lesions; no detectable mycobacteria), lepromatous (multibacillary infection; unstable immunity; diffuse lesions) and borderline (between the lepromatous and tuberculoid forms) [2]. Peripheral nerve involvement typically includes the ulnar and common peroneal nerves, but other nerve trunks may be affected, giving the classical pattern of multiple neuropathy. Electrodiagnosis can help to evaluate the extent of nerve damage, as well as ultrasonography of the PNS. The diagnosis is primarily based on clinical findings, but can be confirmed by histopathological study of skin smears or nerve biopsy (requiring expertise and trained staff; Fig. 1a). Polymerase chain reaction (PCR) testing may also be used to support the diagnosis [2].

Leprosy has always been regarded as the most dreadful of the diseases afflicting mankind. Apparently originating from East Africa, it spread by human migrations to Asia (with osteoarcheological evidences in India by $2000 \mathrm{BC}$ ) then Europe and America [3]: although there are references to leprosy in ancient Egyptian, Greek and Roman (as well as in the Bible), it did not always align with the clinical picture of the disease, the term 'lepra' being then commonly used to refer to 'harmful and unknown skin conditions' (such as 'elephantiasis') [4]. There are also skeletal traces of leprosy during the first millennium in Europe (Fig. 2a) [3]: under the reign of Pepin-the-Short (714-768), King of the Franks, leprosy was admitted as a cause of marriage dissolution, allowing the healthy spouse to remarry. [4] After the Crusades, leprosy peaked in Europe, assuming the features of a pandemic [4]. In the Middle Ages, because it causes visible disfigurement and severe disability, this 'incurable highly contagious disease' was also a reason for social discrimination, so lepers were placed and lived in 'leper colonies' ('leprosarium'), also called 'Lazarette' (this word was derived from the biblical figure Saint Lazarus who Christians believed was cured of his leprosy by Jesus), and the military and hospital 'Order of Lazarus' was established to aid lepers [5]. In 1244, there were nearly 19,000 leprosaria in Christian territories, leprosy being considered 'sacred' for Christians (as a 'divine punishment') [4]. After the fourteenth century, the prevalence of leprosy declined rapidly in Europe, probably in part because of segregation of lepers and excess mortality resulting from other epidemics (plague, tuberculosis, etc.).

In 1847, in Norway, Daniel Danielssen (1815-1894) and Carl Boeck (1808-1875) published a study where they divided leprosy ("Spedalskhed") into two main groups: the 'tuberculous form' (involving the skin) and the 'anesthetic form' (involving the peripheral nerves) [6]. Danielssen and Boeck thought that leprosy resulted from hereditary factors (a widespread idea at that time), but their proposition to confine to hospitals and to prohibit lepers from marrying was rejected by the Norwegian Parliament [7]. Based on epidemiological studies, Gerhard Hansen (1814-1912), who worked in the Bergen Hospital with Danielssen, thought it was an infectious disease and microscopically described "small staff-like bodies" in leprous tissues (rod-shaped bodies known as "Hansen bacillus", corresponding to ML) [8]. However, he did not clearly identify them as bacteria but only suggested they were bacteria. Hansen also failed to stain his preparations so he was helped by Albert Neisser (1855-1916), when Neisser visited Hansen in Norway (1879): it was Neisser who finally gave the first satisfactory evidence of the relationship between ML and lesions of leprosy. [9] This early demonstration of pathogenic bacteria (as for Mycobacterium tuberculosis, MT, or “Koch's tuberculous bacillus") confirmed that germs may be the causes of disease and that social conditions may be related to such diseases [10]. In 1882, Robert Koch (1843-1910) found a method to stain MT. [11] The same year, Paul Ehrlich 


\begin{tabular}{|c|c|c|c|}
\hline & LEPROSY & POLIOMYELITIS & DIPHTHERIA \\
\hline Pathogen & Mycobacterium leprae/lepromatosis & Poliovirus & Corynebacterium diphtheria \\
\hline Mode of transmission & -respiratory route & -fecal-oral route & $\begin{array}{l}\text {-respiratory route } \\
\text {-contact with skin lesions }\end{array}$ \\
\hline Incubation & $3-5$ years & $2-35$ days & 1-10 days \\
\hline First stage of the disease & - & $\begin{array}{l}\text {-asymptomatic } \\
\text {-flu-like illness or gastroenteritis }\end{array}$ & $\begin{array}{l}\text {-flu-like illness } \\
\text {-pseudomembranous pharyngitis } \\
\text {-lymphadenopathy }\end{array}$ \\
\hline $\begin{array}{l}\text { Common neurological } \\
\text { manifestations }\end{array}$ & -multiple mononeuropathies & $\begin{array}{l}\text {-asymptomatic ( } 95 \%) \\
\text {-aseptic meningitis ( } 4 \%) \\
\text {-paralytic polio }(1 \%) \text { : lower motor neuron disorder }\end{array}$ & $\begin{array}{l}\text {-bulbar palsy } \\
\text {-acute sensorimotor demyelinating polyneuropathy }\end{array}$ \\
\hline $\begin{array}{l}\text { Common extra-neurological } \\
\text { manifestations }\end{array}$ & -skin hypopigmentation & - & $\begin{array}{l}\text {-cardiac arrythmia / myocarditis } \\
\text {-cutaneous lesions }\end{array}$ \\
\hline Therapeutic & Rifampicin + Dapsone \pm Clofazimine & $\begin{array}{l}\text {-supportive measures } \\
\text {-support breathing (if respiratory palsy) }\end{array}$ & diphtheria antitoxin \\
\hline
\end{tabular}

B

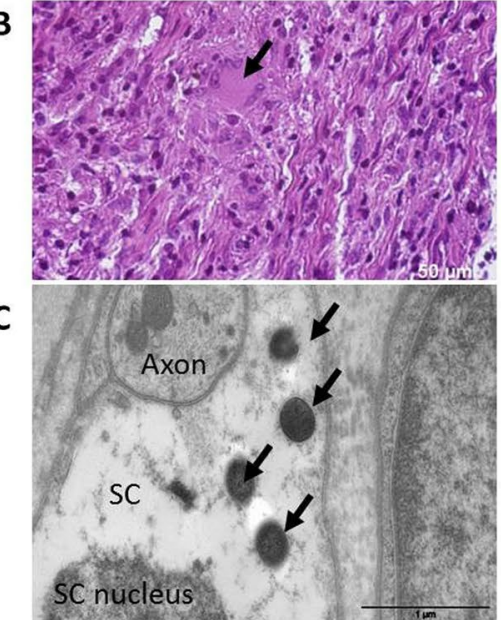

D

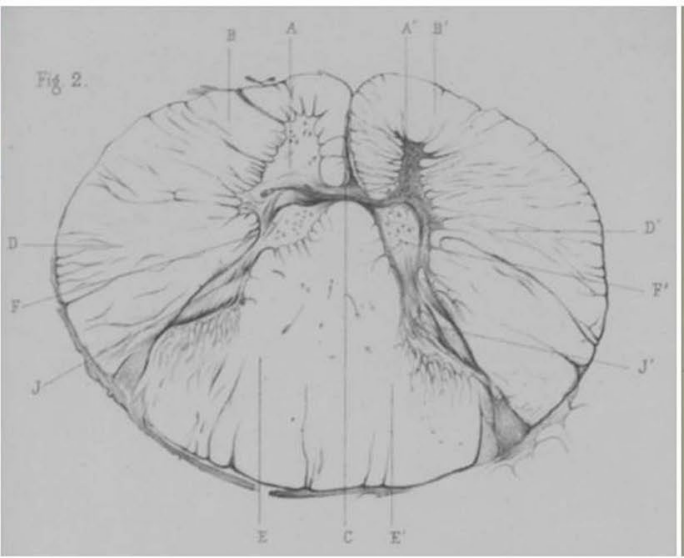

$\mathbf{E}$

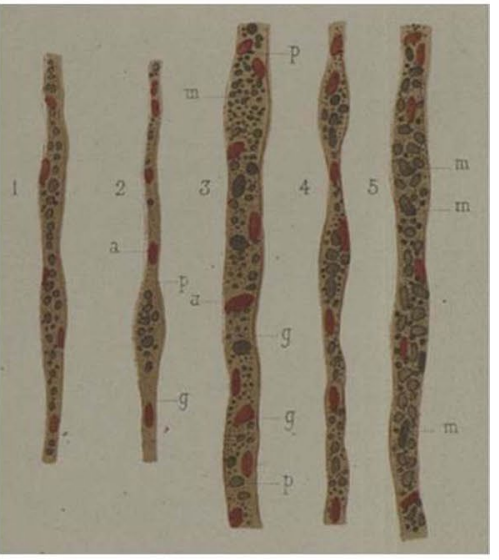

Fig. 1 Main clinical and pathological characteristics of leprosy, poliomyelitis and diphtheria. a Table summarizing the main clinical characteristics of leprosy, poliomyelitis and diphtheria. b Leprosy. nerve biopsy (personal case; transverse section; light microscopy, hematoxylin-eosin) showing tuberculoid leprosy; in this nerve fascicle, granulomatous lesions heavily infiltrate the endoneurium: macrophages, histiocytes, lymphocytes and giant cells (Langerhans cells) (arrow). c Leprosy. nerve biopsy (personal case; transverse section; electron microscopy) showing the presence of four Hansen bacilli (arrows)

(1854-1915) improved Koch's method (he decolorized with a mineral acid, used fuchsin and changed the mordant to aniline oil) [12] and Franz Ziehl (1859-1926) introduced the carbol fuchsin stain [13]. Then, in 1883, Friedrich Neelsen (1854-1898) combined Zielh's mordant with Ehrlich's red stain and obtained the acid-fast stain [14]: this is nowadays known as 'Ziehl-Neelsen's stain', a method frequently used for the diagnosis of mycobacteria, especially in leprosy.

Danielssen and Boeck first proposed the term "anesthesic leprosy" to describe leprosy with sensory disturbance [6], but other terms were used, such as the "lepra nervorum" described by Rudolf Virchow (1821-1902). Virchow was the first to describe lipid-accumulating macrophages in peripheral nerves from patients with lepromatous leprosy [15]: nowadays known as "Virchow's cell " ("lepra cells" in a Schwann cell (SC) cytoplasm. d Poliomyelitis. Drawing of the paper of Charcot and Joffroy (1870; Figure V.2; with the permission of the "Bibliothèque de France") showing atrophy of the anterior horns (A and A') in a case of 'infantile spinal atrophy'-transverse section of the spinal cord at the level of the dorsal part of the spine). e Diphtheria. Drawing of the paper of Dejerine (1878; Fig. XVII.1; with the permission of the "Bibliothèque de France") showing severe axonal lesions (with ovoids) in a case of diphtheritic paralysis (picrocarmin staining)

or "foamy cells"), they are distinctive of the severe form of lepromatous leprosy; ML resides and replicates within Virchow's cells [16]. In 1892, Albert Pitres (1848-1928) highlighted the importance of bacteriological investigations (using Zielh-Neelsen stain) for diagnosing leprosy in patients with few symptoms (especially when PN is due to leprosy), and wrote: "However, it is not essential that the nerves be the site of nodular indurations or caseous degeneration without the presence of specific microbes, since in our case, the examined nerve fragment was neither swollen nor caseous. However, it is obvious that, under these conditions, an examination with negative results would not absolutely prove that we are not dealing with a case of leprosy, since not all nerves of leprosy patients are uniformly infiltrated with bacilli" (translated from the French) [17]. 


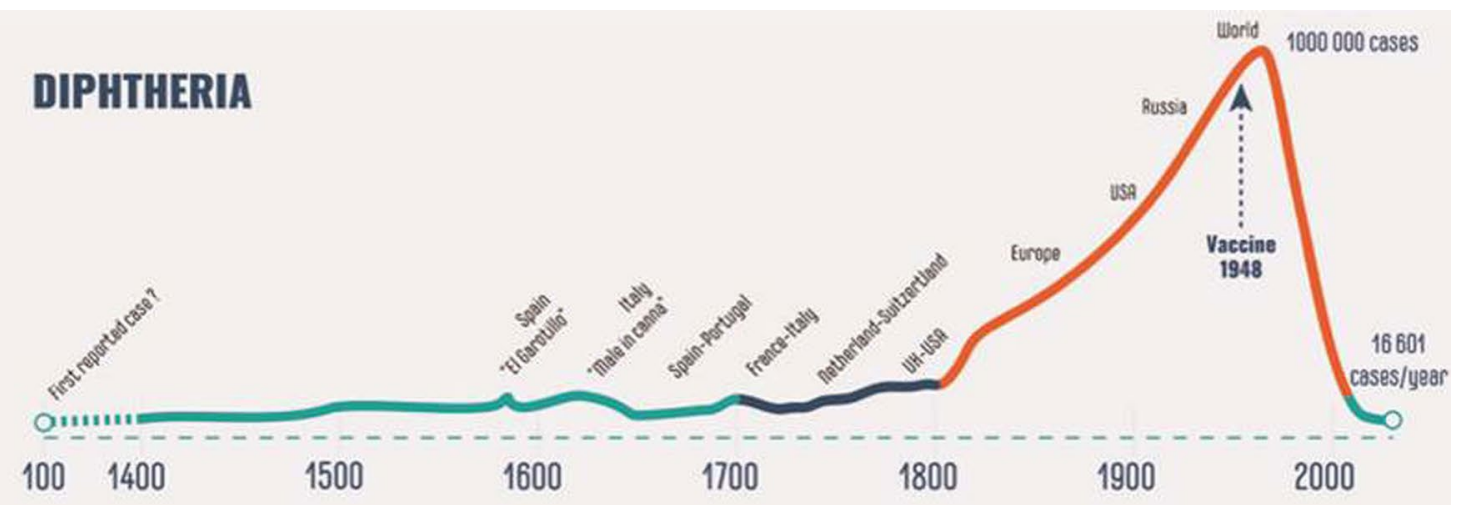

Epidemic Endemic Pandemic

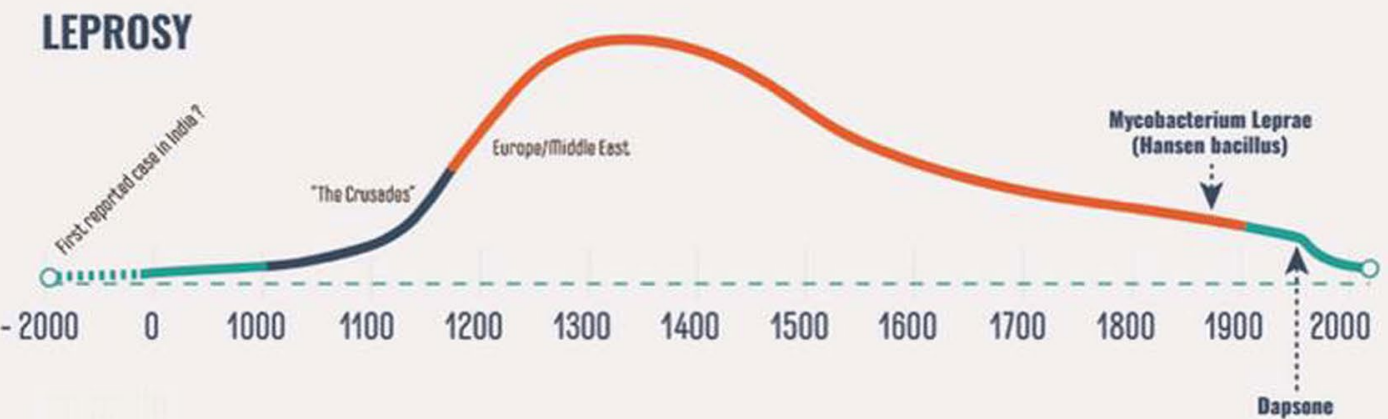

\section{POLIOMYELITIS}

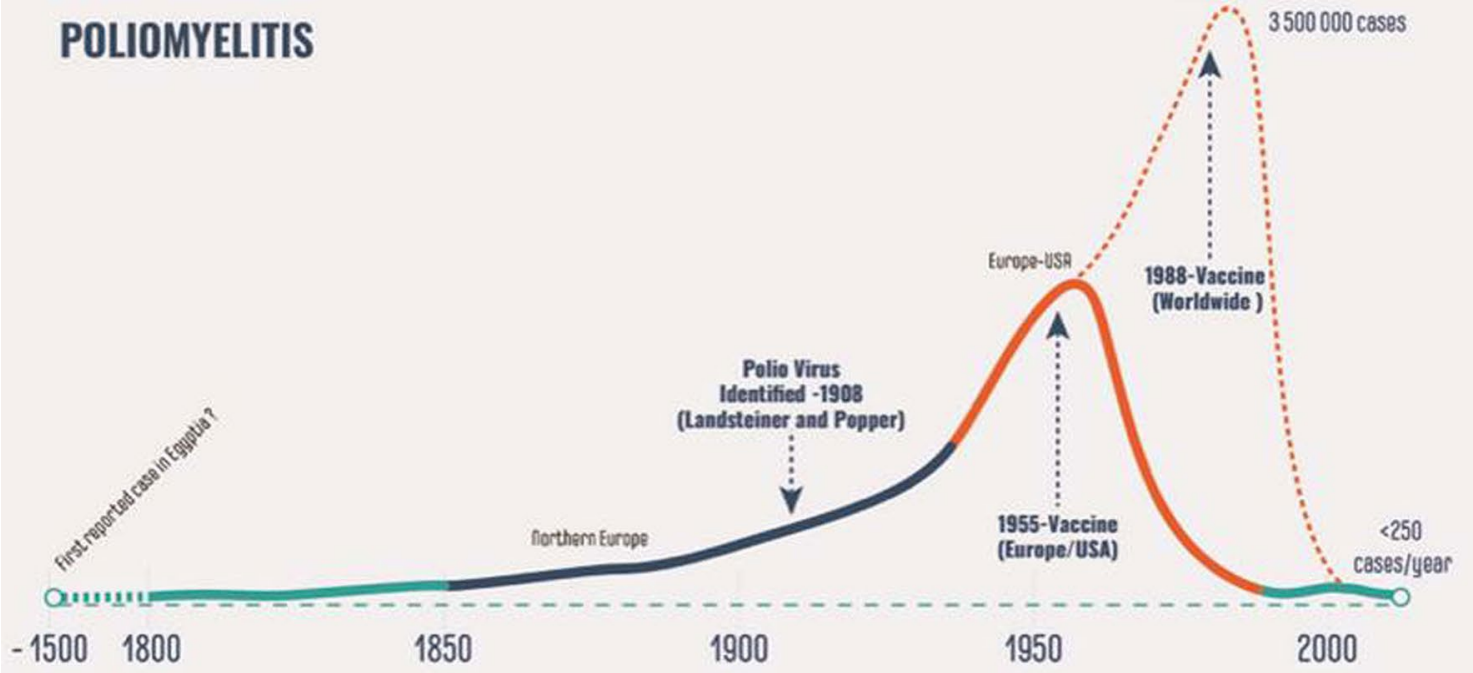

Fig. 2 Schematic chronological representation of the main infectious epidemics affecting the peripheral nervous system (poliomyelitis, leprosy and diphtheria) 
Lepers were first treated by chaulmoogra oil, used over centuries in Indian and Chinese medicine, introduced in Europe in the nineteenth century. Sulfones are used since the 1940's as a more efficient treatment [18], nowadays associated with antibiotics (rifampicin and/or clofazimin). Leprosy was declared "eliminated" by the World Health Organization (WHO) in 2000: although it is now rare in developed countries, the worldwide prevalence is still as high as 250,000 new registered cases each year [19].

\section{Poliomyelitis}

The first probable reference to poliomyelitis (polio) comes from Egypt, 3000 years ago (Fig. 2b) in a stele depicting a man with atrophic leg and deformed foot (assumed to be Ruma) and in the written description of the Pharaoh Siptah (1200 BC-1193 BC) who was stricken with a "paralyzing disease" when he was a young boy [20]. There are also many references to polio in the Bible [20]. Since the eighteenth century, sporadic cases of polio were reported, always referring to children, such as the "debility of the extremities" described by Michael Underwood (1736-1820) [21]. In 1840, the German surgeon Jakob Heine (1800-1879) described a series of 30 late paralytic cases with muscle atrophy he called "infantile spinal paralysis" [22]. In the following years, spinal cord lesions were suspected by some physicians such as Guillaume-Benjamin Duchenne de Boulogne (1806-1875), an observation that was confirmed by Jean-Martin Charcot (1825-1893) and Alix Joffroy (1844-1908) in 1870, the neurological lesions being accurately located in the anterior horns of the spinal cord (Fig. 1b) [23]. The term "poliomyelitis" was finally proposed by Wilhelm Erb (1840-1921) in 1875, a word derived from the Greek "polios" ("gray") and "myelos" ("spinal cord") [24]. 50 years after Heine, following an outbreak in Sweden, Karl Medin (1847-1927) highlighted the epidemic character of the disease although some authors such as Charles Bell (1774-1842) had described some "groups of cases" in the mid nineteenth century [25]. Medin also demonstrated that polio is transmitted through the digestive tract, so this neurological disease was referred as an intestinal infection (oral-fecal contact transmission exacerbated by poor sanitary conditions) [25]. In 1907, observing that polio spread was irregular (many patients having no direct contact with a known source), Ivar Wickman (1872-1914), one of Medin's pupils, confirmed the contagious character of the disease and proposed to name it 'Heine-Medin disease'. [26].

In 1909, Karl Landsteiner (1868-1943) and Erwin Popper (1879-1955) showed that a virus (transmissible to monkeys) was the cause, an enterovirus belonging to the Picornaviridae family (later called "poliovirus"). [27] However, the diagnosis of poliomyelitis remained clinical and difficult, suspected in cases of paralysis of the lower limbs or ascending paralysis (sometimes affecting the diaphragm and cranial nerves), occurring after fever: this description is close to those of the 'axonal motor form of Guillain-Barré syndrome' (described many years later). The period between the First and Second World Wars was one of great advances in virology, while at the same time, polio outbreaks gradually became more severe, more frequent and widespread throughout Europe and the USA although using isolation and quarantine (patients, usually children, were often separated from the family and sent to sanatoria) [5].

Three different strains of the poliovirus were finally identified (I: 'Brunhilde'; II: 'Lansing'; III: 'Leon'), each strain giving different forms of the disease (I: common, with limb paralysis; II: mild or asymptomatic cases; III: rare, with severe bulbar symptoms and respiratory failure) [5]. In 1954, John Enders (1897-1985) and collaborators received the Nobel Prize for having cultured the 'Lansing strain' of poliovirus in embryonic tissue culture, opening the way to the culture of other viruses (such as coronavirus) [28]. Since 1955, using extensive vaccination, the incidence of polio dramatically declined, the disease being nowadays virtually eradicated in Europe and the USA. However, global eradication of polio is still challenging, and wild-type virus continues to affect Sub-Saharan Africa and the Indian subcontinent: it is still endemic in some countries (Nigeria, Pakistan and Afghanistan). [5] Moreover, outbreaks of polio were observed following the use of oral poliovirus vaccine, giving 'vaccine-associated paralytic polio' (VAPP): the use of 'inactivated polio vaccine' avoids the occurrence of VAPP [29].

\section{Diphtheria}

As with leprosy and polio, diphtheria was probably recognized in antiquity (Fig. 2c): Aretaeus of Cappadocia (first century AD) found that what he called 'syriac ulcers' was originated from Syria and Egypt [30]. Then, many deadly epidemics of childhood throat infections observed in Europe were variously named 'cynanche trachealis', 'angina maligna contagiosa', 'angina suffocativa', 'sore throat distemper', 'croup', 'el garratillo', 'morbus suffocans', etc. [30] This disease is caused by Corynebacterium diphtheria, a bacteria spread through airborne respiratory droplets and nasal secretions (or by direct contact with infected skin ulcers), that can live for weeks on fomites. Classically, after a 2-7 day period of incubation, patients, usually children, develop a sore throat (with little or no fever) then bacteria release exotoxin causing throat inflammation, cell necrosis and puslike exudate (grayish pseudomembrane adhering to throat, soft palate and larynx). Because of this "false membrane", Pierre Bretonneau (1778-1862), distinguishing it from scarlet fever, proposed the name "diphthetitis" (from the Greek "diphtheria" meaning "leather") in 1821, before one of his 
pupils, Armand Trousseau (1801-1867), proposed to simply use the term "diphtheria" (giving less importance to inflammation) for this disease that became pandemic in the nineteenth century [30]. In 1883, Corynebacterium diphtheria (Klebs-Loeffler bacillus) was identified by Edwin Klebs (1834-1913) in pseudomembranes, cultivated 1 year later by Friedrich Loefller (1852-1915) [31]: as they supposed, the existence of the diphtheria toxin was confirmed by Emile Roux (1853-1933) and Alexandre Yersin (1863-1943) in 1888 [32].

Long considered as a local complication of respiratory obstruction (larynx inflammation), death may result from the effects of exotoxin on myocardial and neural tissues. Nowadays, bulbar palsy is a well-known complication of diphtheria, but we have to go back to the middle of the eighteenth century to find evidence of the description of diphtheritic bulbar palsy by Jean-Baptiste-Louis Chomel (1709-1765) [33]. In the beginning of the nineteenth century, if "weakness in the muscle strength of the lower limbs" was reported by some, the relationship between sensorimotor disturbance of the limbs and diphtheria was more probably observed by Arsène Orillard (1806-1879) in 1837 [34]. First considered as "sine materia paralysis", diphtheritic paralysis was linked to peripheral nerve damages in 1862, when Charcot and Alfred Vulpian (1826-1887) observed microscopic lesions of the palatine nerves (close to that observed in case of nerve section) [35]. In 1870, Ernst Leyden (1832-1910) described microscopic lesions of 'neuritis migrans' (diphtheritic polyneuropathy) [36], later confirmed by Jules Dejerine (1849-1917) who consistently observed lesions of the anterior spinal roots and parenchymal neuritis in the paralyzed limbs (Fig. 1c) [37]. Typical diphtheritic polyneuropathy begins with soft palate paresis, paresthesia and paresis of the extremities of the upper limbs (then the lower limbs), the main differential diagnosis being the pharyngocervicobrachial variant of Guillain-Barré syndrome [38]. Treatment is based on the administration of diphtheria antitoxin and antibiotherapy. The global incidence of diphtheria in industrialized countries decreased rapidly with the introduction of diphtheria-tetanus-pertussis (DTP) vaccine after World War II, but it still remains a public health problem (endemic) in many developing countries [38].

\section{The immune-mediated causes}

\section{Guillain-Barré syndrome and epidemics}

GBS was officially described in 1916 during the First World War [39], but earlier cases were observed and described in various terms [40]. Although most of the reported cases were isolated ones, such as those described by Guillain et al. [40], some had observed the seasonal incidence of GBS at the end of the nineteenth century. Since the first descriptions of 'Landry's paralysis' (and even before), exposure to cold and overexertion were considered as causes [40]: in Boston (1884), Samuel Webber (1838-1926) observed "an unusually large number of cases entered the City Hospital-eighteen" during "the fall and winter of' 83- '84" [41]. In 1917, Sir Gordon Holmes (1876-1965) also related similar observations, writing: "Such cases have often been observed in irregular epidemic form, generally during the winter, but they also occur sporadically" [42].

The cause and exact pathophysiology of GBS has long been a source of debate. Observing that "their onset is usually acute and almost always associated with a rise of temperature", Holmes described it as "acute febrile polyneuritis" [42], a term already used by Sir William Osler (1849-1919) in 1892 [40]. The situation became more complex following the description of numerous cases of "epidemic encephalitis" ("lethargic encephalitis", LE) during the First World War, simultaneously reported in France by René Cruchet (1875-1959) [43] and in Austria by Constantin von Economo (1876-1931) [44], then worldwide spread (until it almost disappeared in 1928 with only sporadic cases). Three main variants of LE were described (the "somnolent-ophthalomoplegic form", the "hyperkinetic form" and the "amyostatic akinetic form") [45], but some authors also described a "peripheral form of epidemic encephalitis" (PFEE): such patients presented the clinical picture of GBS (with albumino-cytologic dissociation) associated with cranial nerve palsy (so the term "encephalitis" was used) [46]. At that time, LE was supposed to be due to a neurotropic virus that nobody could identify. Interestingly, LE appeared around the same time as the great influenza pandemic (1918), but the link between both was never proved [45]. In comparison to LE, one explanation for PFEE was the role of a neurotropic virus that only involved the PNS. Because of the pathologic findings showing demyelinating lesions of the peripheral nerve (with abnormal Schwann cells), PFEE (GBS with cranial nerve palsy) was supposed to be a "septinevritis due to schwannophilic ultravirus" [47].

In 1941, Sabin and Aring suggested that the neuropathologic changes observed in GBS could be secondary to "toxins" produced during infections that precede the onset of the disease [48]. But it was not until many years later, with the emergence of the concept of "experimental allergic neuritis", [49] and after the works of Haymaker and Kernohan, that pathophysiologic knowledge about GBS made good headway [39]: since the 1970s, GBS is no longer regarded as an infectious disease, but as a "cell-mediated immunologic disorder, in which peripheral nervous tissue, in particular myelin, is attacked by specifically-sensitized lymphocytes" [50], a prototype for immune-mediated postinfection disease. 


\section{Acute infantile paralysis: acute anterior poliomyelitis or 'axonal Guillain-Barré syndrome'?}

In 1969, Ramos-Alvarez et al. reported the postmortem study of 57 Mexican children with acute paralysis, 32 poliomyelitis and 25 with no inflammatory changes in the central nervous system ( 10 were compatible with GBS, eight were considered as "cytoplasmic neuronopathy" and seven were considered as "nuclear neuronopathy"), highlighting that all the acute infantile paralysis are not poliomyelitis and are not strictly GBS [51]. In 1978, an outbreak of 16 cases of acute paralysis (with no evidence for poliomyelitis) was observed in Jordan, motor weakness occurring the third week of a diarrhea epidemic caused by "water pollution" [52]. During the 1970's and the 1980's, more than 1,000 similar cases were reported among children (and young adults) in rural parts of Northern China, with a seasonal distribution (peak incidence in late summer and early fall): this "Chinese paralytic syndrome", differing from poliomyelitis, was characterized by a prodromal illness (usually diarrhea), symmetric ascending weakness over days, normal sensation, and elevated CSF protein level in many cases [53]. On the basis of clinical criteria and CSF analysis, GBS was suspected; but electrodiagnostic evaluations were suggestive of a severe motor neuropathy (sparing sensory fibers) [53]. In 1990, this "axonal form of GBS", finally called "acute axonal motor neuronopathy" (AMAN), was linked to Campylobacter jejuni infection and antibodies against GM1 (mono-sialotetrahexosyl-ganglioside), the sensorimotor variants being called AMSAN ("acute motor and sensory axonal neuropathy") [39]. Nowadays, AMAN and AMSAN are considered as nodo-paranodopathies [39].

\section{Guillain-Barré syndrome and emerging infectious diseases}

The annual incidence of GBS is $0.81-1.89 / 100,000$ persons in Western countries. [54] Although Campylobacter jejuni (because a lipo-oligosaccharide present in the outer membrane of this bacteria is similar to gangliosides that are components of the peripheral nerves) is a common trigger of GBS (identified in up to one-third of the patients), many other infections have been linked to GBS. Up to $70 \%$ of patients report an illness in the 1-6 weeks before the first symptoms of GBS, other common microorganisms being cytomegalovirus, varicella-zoster virus, Epstein-Barr virus and Mycoplasma pneumonia [54]. In recent years, some GBS outbreaks have been linked to emerging viruses, the best example being Zika virus (ZIKV).

Linked to dengue (DENV) and chikungunya (CHIVKV) arboviruses, ZIKV is a newly emergent relative of the flaviviridae family. First isolated in 1947, in the blood of a sentinel rhesus macaque (Ziika Forest, Uganda), ZIKV is a single-stranded RNA-enveloped arthropod-borne virus transmitted by Aedes mosquitoes (Fig. 3) [55]. ZIKV infection was sporadically observed in some African and Asian countries until its epidemic capacity was revealed in the southwestern Pacific Ocean (2007), South Pacific (2013-2014), then South America, Latin America and the Caribbean (2015-2016) (Fig. 3) [56]. Before 2013 ZIKV was not known to provoke neurological complications, but many cases of GBS were then linked to ZIKV, with three strains of ZIKV (two from Africa, then one from Asia that spread in the South Pacific and America) supporting an expansion of its lineage with several recombination events [55]. During the 6-month period of the French Polynesia arboviral epidemic (2013-2014), 28,000 cases of ZIKV infection were observed (10\% of the total population): among them, 42 cases of GBS were reported (with a pattern more suggestive of AMAN/AMSAN), versus $<2$ annual usual cases in this area [55]. In Latin America and the Caribbean, GBS incidence was estimated to have increased 2.6 times during the ZIKV outbreak [56]. It was hypothesized that ZIKV-GBS may be due to dysregulation of the activity of the RNA editing enzymes [57].

A sudden outbreak of GBS was observed in 2018, in Peru, with the classical picture of GBS but with pain of the extremities, likely associated with an enterovirus infection [58]. More anecdotally, some GBS were reported during dengue or chikungunya epidemics [59]. Recently, some cases of acute polyradiculitis have been reported in association with COVID-19, akin to GBS due to other triggers [60].

In October 2007, 12 cases of polyradiculoneuropathy were identified at a pork abattoir in Southeast Minnesota (USA), referred as "primary inflammatory neuropathy" (PIN) [61], and similar cases were then reported in Indiana (USA): during November 2006 and May 2008, 24 cases were finally observed ( 21 from Minnesota, 3 from Indiana) [62]. The first symptoms of PIN were sensory (numbness, tingling) then motor weakness, ranging from acute onset to gradually progressive symmetric weakness (from a period to 2-213 days) [61, 63]. Three patients developed aseptic meningitis, transverse myelitis, and meningoencephalitis, which were followed by a painful polyradiculoneuropathy [62]. High CSF protein level was observed in 18 among 21 patients with lumbar puncture (pleicytosis in only 3 patients) [62]. Nerve conduction studies showed prolonged distal motor and sensory latencies, prolonged F-wave latencies, prolonged trigeminal blink responses, distal sweat loss on thermoregulatory sweat testing, and distal abnormalities on quantitative sensory testing [62]. Enlargement and enhancement of nerve roots and ganglia was observed on MRI. Sural nerve biopsies (4 patients) showed findings of inflammatory demyelinating PN [62]. Improvement was observed in 17 patients, after treatment with intravenous immunoglobulin, plasma exchange, intravenous methylprednisolone or oral 


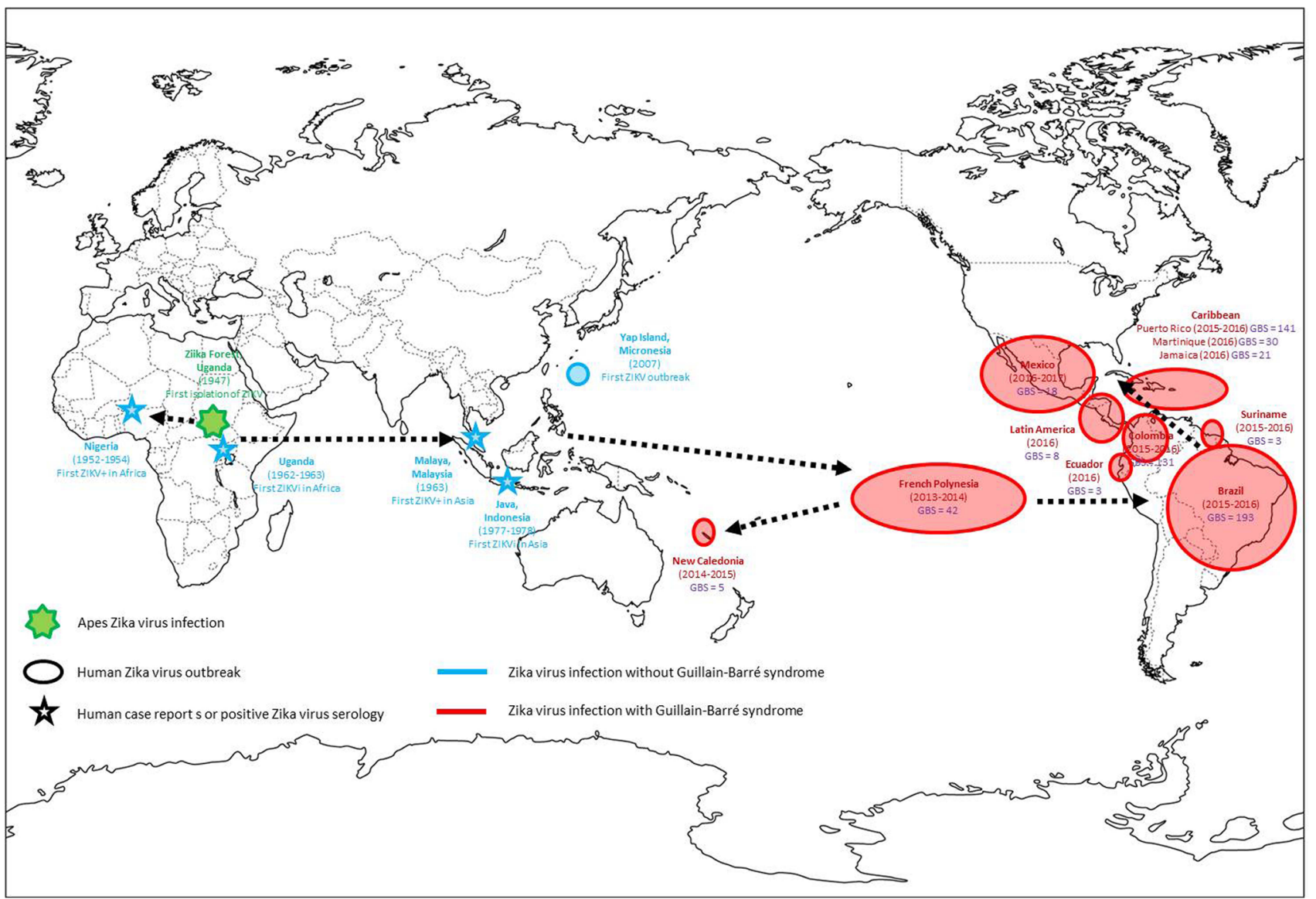

Fig. 3 Main steps in the history and emergence of Zika virus (ZIKV) and Guillain-Barre syndrome (GBS); ZIKV+ serum positivity to ZIKV; ZIKVi:ZIKV infection

prednisolone [62]. PIN occurred in workers who had close contact with swine brains or by removing brains using compressed air. It is a immune-mediated PN related to occupational exposure to multiple aerosolised porcine brain tissue antigens: a vulnerability of nerve roots and terminals where the blood-nerve barrier is most permeable was suggested [62]. Recently, it has been suggested that the immune attack is probably directed against a nodal or paranodal antigen rather than the internode [64].

\section{Guillain-Barré syndrome and influenza vaccination}

According to epidemiologic studies, influenza could be a significant and underestimated etiology of GBS that may occur within three months after the influenza-like illness (although the mechanism underlying influenza-associated GBS is not clearly known), the more recent example being the influenza-A pandemic in 2009 (H1N1-pdm09), with a relative risk of GBS of 4.89 in $\mathrm{H} 1 \mathrm{~N} 1$ patients [65]. But, vaccination is also a possible trigger of GBS.

Thus, in 1976, an increased incidence of GBS was reported following a large-scale vaccination campaign against swine influenza (New Jersey, US), raising doubts about the safety of influenza vaccination [66]. However, with the exception of this 1976 vaccination campaign, there is no proven association between the incidence of GBS and influenza vaccination: influenza vaccine represents a minimal risk of GBS (mainly observed in pandemic vaccination), with an attributable risk estimated to be $1-3 / 1,000,000$ [67]. This risk was especially present when using the old formulation of rabies vaccine that is no longer available [67]. Vaccines other that against influenza, including current rabies vaccine, have not been shown to cause GBS [67].

\section{Peripheral neurological complications of human immunodeficiency virus infection}

Acquired immunodeficiency syndrome (AIDS), first recognized as a human disease in 1981 (mainly with sexually transmission), is caused by two lentiviruses (within the family of Retroviridae) that are highly replicative and cytopathic against cells of the immune system: human immunodeficiency viruses types 1 (HIV-1) and 2 (HIV-2). HIV-1 is the most common and pathogenic strain of the virus: it includes 
four groups ( $\mathrm{M}, \mathrm{N}, \mathrm{O}$ and $\mathrm{P})$, the group-M representing the most frequent ones (95\%) and responsible for the AIDS pandemic. HIV-2 is thought to be less virulent and transmissible than HIV-1 group-M. Like poliovirus or ML HIV-1 is one of the most successful pathogens in human history, the AIDS pandemic having infected more than 60 million people worldwide, with an annual incidence of 1.9 million people in 2013 [68].

HIV-1 and HIV-2 were the result of multiple crossspecies transmissions of simian immunodeficiency viruses (SIV) naturally infecting some Western African primates: chimpanzee and gorilla SIV are the closest relatives of HIV1, although mangabey monkey SIV are close to HIV-2 [68]. HIV-1 developed from zoonotic transmission of different SIV from chimpanzees belonging to Pan troglodytes troglodytes (Southern Cameroon): using phylogenetic technique, the origin of group-M HIV-1 was dated to 1921, whereas HIV-2 was transmitted zoonotically from mangabey to humans in the 1940's. HIV-1 was exported to Haiti in 1966, and has been present in North America since 1968. The current pandemic is due to the spread of HIV-1 since the 1980's [68].

Before the advent of combined antiretroviral therapy (ART), HIV-infected patients suffered from high mortality and morbidity (including neurological manifestations, through direct or indirect mechanisms), and the prevalence of long-term HIV-related neurologic complications (affecting both the central and peripheral nervous system) continues to rise: the neurological complications may be due to primary HIV infection or secondary to opportunistic infection, or associated with ART; moreover, new inflammatory syndromes (so-called 'immune reconstitution inflammatory syndromes', IRIS) were observed (resulting from immune recovery following initiation of ART) [69]. Peripheral neuropathy is the most common neurological complication (associated with all stages of HIV infection), occurring in $30-67 \%$ of HIV patients. This is typically a chronic axonal distal sensory polyneuropathy where chronic inflammation leads to distal degeneration of long axons and neuronal loss in the dorsal root ganglia. Another cause is antiretroviral drug toxicity (probably leading to mitochondrial dysfunction), usually appearing 2-3 months after the initiation of ART (especially the dideoxynucleosides): in such case, withdrawal or dose reduction of ART dose should be envisaged [69]. Sensorimotor polyneuropathies and polyradiculoneuropathies are less frequent, but have potentially devastating consequences [69]. HIV-related GBS is thought to occur more frequently in the context of a preserved CD4cell count, or as an HIV seroconversion illness: the clinicoelectrophysiological pattern is the same as for "classical GBS', but pleocytosis should alert the clinician to underlying HIV infection [69]. Other rare peripheral neurological complications are chronic inflammatory demyelinating polyradiculoneuropathy (sometimes with a multifocal pattern), mononeuropathies (especially cranial neuropathies), autonomic neuropathy, diffuse infiltrative lymphocytosis syndrome and lumbosacral radiculopathy [69].

\section{Lyme disease: an increasing public health problem}

Lyme disease (borreliosis) is a zoonotic disease caused by Borrelia burgdorferi (BB) (transmitted to humans and domestic animals by the bite of the Ixodes tick) causing erythema migrans. BB was found in Ötzi, an iceman mummy 5,300-years old [70]. The first probable description of some clinical symptoms of the disease was by the Reverend John Walker (1731-1803) when he visited the island of Jura in the Hebrides (Scotland), writing: "Over the highlands in general there are fewer people to be observed either lame or decrepit than in any other country perhaps in Europe. But in the island of Jura, the cripples are remarkably numerous; owing to a very singular disease with which this island is peculiarly infected"; "This disease arises from a worm lodged under the skin, that penetrates with exquisite pain, the interior parts of the limbs. It is termed in the Galic language Fillun"; "The worm disappears soon after this stage of the disease, but when it is suffered to come this length, it never fails to cripple the patient for life. And the intense pain with which it is accompanied sometimes destroys the appetite and spirits and occasions death" [71]. In October 1909, 28th, Arvid Afzelius (1857-1923) reported on the characteristic ring-like erythema ("erythema migrans") [72], called "erythema chronicum migrans" 3 years later by Benjamin Lipschütz (1878-1931) [73]. In 1976, in an abstract, Steere et al. reported on 35 patients from Lyme (Connecticut, US) who developed arthritis between 1973 and 1975 [74]. The spirochete causing "Lyme disease" was finally isolated in 1982 by Willy Burgdorfer (1925-2014) and his team [75]. Evidence indicates that borreliosis is on the rise in both North America and Europe, and the number of cases is probably significantly underestimated: the annual incidence in the USA was estimated to be 30,000 cases/year in 2013, but the true incidence could be 10 times that number [76].

A classical neurological complication of borreliosis is meningo-radiculitis, fully described by Alfred Bannwarth (1903-1968) in 1941 [77]. However, two French physicians, Charles Garin (1883-1971) and Charles Bujadoux (?), probably described it in 1922 with fewer details [78]. Meningo-radiculitis is the most common manifestation of neuroborreliosis, other peripheral neurological complications being mononeuritis multiplex, cranial nerve palsy and facial diplegia. In meningo-radiculitis, it is not clear whether the peripheral nerve lesions are due to due to the dissemination of $\mathrm{BB}$ along the nerve tracts to the respective spinal roots [77] or to a dysimmune process: although inflammatory cells and axonal lesions have been observed 


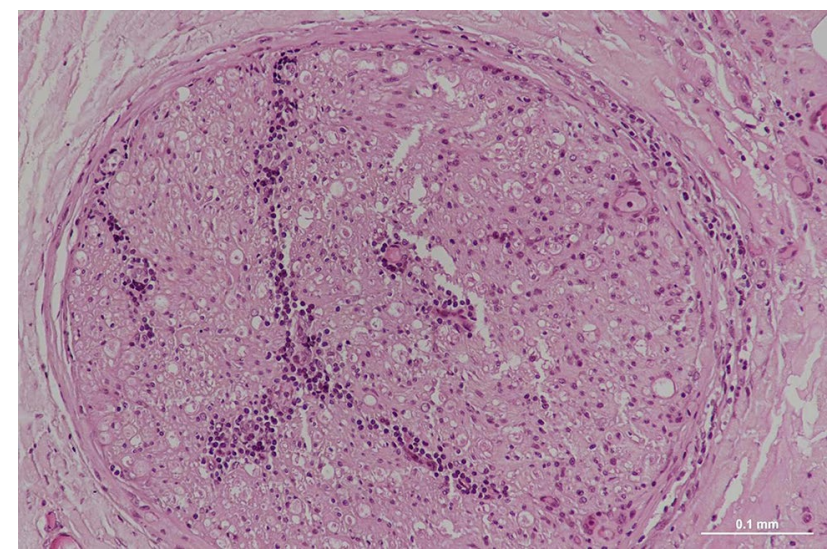

Fig. 4 Paraffin-embedded transverse section of one fascicle of the nerve biopsy of a patient with neuroborreliosis (hematein-eosin staining) showing infiltrations of lymphocytes and plasma cells, sometimes forming thick pericapillary cuffs with no accompanying necrosis of vessel walls; many capillaries of the endoneurium, perineurium, and epineurium are affected in this way

in the peripheral nerves/roots (Fig. 4), BB has never been identified by electron microscopy [79]. This is a treatable condition, but regarding the growing threat that borreliosis represents, and because of the absence of an effective vaccine, patients should be advised to use insect repellent and wear long pants when walking in the woods of endemic areas [76].

Acknowledgement We thank Jackie Stewart (www.graphandart.com) for help with Fig. 2.

Author contributions MS: Pellegrin Hospital (CHU Bordeaux), France; study concept and design, acquisition and interpretation of data, drafting of the manuscript SA: Pellegrin Hospital (CHU Bordeaux), France; critical revision of the manuscript. VJ-M: Dupuytren Hospital (CHU Limoges), France; critical revision of the manuscript. LMG: Pellegrin Hospital (CHU Bordeaux), France; critical revision of the manuscript.

Funding No targeted funding reported.

\section{Compliance with ethical standards}

Conflicts of interest The authors report no disclosures relevant to the manuscript.

Ethical approval This paper does not contain any studies with human participants or animals performed by any of the authors.

\section{References}

1. Gensini GF, Yacoub MH, Conti AA (2004) The concept of quarantine in history: from plague to SARS. J Infect 49:257-261
2. Maymone MBC, Laughter M, Venkatesh S et al (2020) Leprosy: clinical aspects and diagnostic techniques. J Am Acad Dermatol 83:1-14

3. Spigelman M, Rubini M (2016) Paleomicrobiology of leprosy. Microbiol Spectr. https://doi.org/10.1128/microbiolspec

4. Gibert CM (1840) Remarques historiques et critiques sur la lèpre. Rev Med Franc Etrang 3:19-44

5. Byrne JP (2008) Encyclopedia of pestilence, pandemics, and plagues. Greenwood Publishing Group, Westport

6. Danielssen DC, Boeck CW (1847) Om spedalskhed. C. Gröndahl, Christiania

7. Irgens LM, Bjerkedal T (1973) Epidemiology of leprosy in Norway: the history of the National Leprosy Registry of Norway from 1856 until today. Intern J Epidemiol 2:81-89

8. Hansen GHA (1874) Undersøgelser Angående Spedalskhedens Årsager. Norsk Mag Laeger 4:1-88

9. Fite GL, Wade HW (1955) The contribution of Neisser to the establishment of the Hansen bacillus as the etiologic agent of leprosy and the so-called Hansen-Neisser controversy. Int J Lepr 23:418-428

10. King F, Rabson SM (1984) The discovery of Mycobacterium leprae. Am J Dermatopathol 6:337-343

11. Die KR, der Tuberculose A (1882) Berlin Klin Wochen 19:221-230

12. Ehrlich $P$ (1882) Aus dem Verein für innere Medicin zu Berlin. Deutsch Med Wochen 8:269-270

13. Ziehl F (1882) Zur Färbung des Tuberkelbacillus. Deutsch Med Wochen 8:451

14. Neelsen F (1883) Ein casuistischer Beitrag zur Lehre von der Tuberkulose. Centralbl Med Wissen 21:497-501

15. Virchow R (1863) Lepra anesthetica. In: Virchow R (ed) Die Krankhaften Geschwülste Dreissig Vorlesungen, gehalten während des Wintersemesters 1862-1863 an der Universität zu Berlin. August Hirschwald, Berlin, pp 521-526

16. Chatterjee KR, Das Gupta NN, De ML (1959) Electron microscopic observations on the morphology of Mycobacterium leprae. Exp Cell Res 18:521-527

17. De la Pitres A (1892) valeur de l'examen bactériologique dans le diagnostic des formes frustres et anormales de lèpre. Bull Acad Med 28:735-743

18. Faget GH, Pogge RC, Johansen FA, Dinan JF, Eccles CG (1943) The promin treatment of leprosy. A progress report. Pub Health Rep 58:1729-1741

19. Rodrigues LC, Lockwood D (2011) Leprosy now: epidemiology, progress, challenges, and research gaps. Lancet Infect Dis 11:464-470

20. Hecht A (2009) Deadly diseases and epidemics: Polio, 2nd edn. Chelsea House Publishers, New York

21. Underwood M (1789) Debility of the lower extremities. In: Underwood M (ed) A treatrise on the diseases of children. London J Mathews, pp 53-57.

22. Heine $\mathbf{J}$ (1840) Lähmungszustände der untern Extremitäten und deren Behandlung. Franz Heinrich Köhler, Stuttgart

23. Charcot JM, Joffroy A. Cas de paralysie spinale infantile avec lésions des cornes antérieures de la substance grise de la moelle épinière. Arch Physiol Norm Pathol 1870:134-152.

24. Erb W (1875) Ueber acute Spinallähmung (Poliomyelitis anterior acuta) bei Erwachsenen und über verwandte spinale Erkrankungen. Arch Psy Nervenkrank 5:758-791

25. Medin O (1890) En epidemi af infantil paralysi. Forhandl Svenska Lak Samm 52:657-668

26. Wickman I (1907) Beiträge zur kenntnis der Heine-Medinschen Krankheit. S. Karger, Berlin

27. Landsteiner K, Popper E (1909) Übertragung der Poliomyelitis acuta auf Affen. Zeitschrift für Immunitätsforschung und experimentelle Therapie 2:377-390 
28. Baicus A (2012) History of polio vaccination. World J Virol $1: 108-114$

29. John TJ (2004) A developing country perspective on vaccine-associated paralytic poliomyelitis. Bull World Health Organ 82:53-57 discussion 57-58

30. Kelsch AD. In: Kelsch A, ed. Traité des maladies épidémiques Etiologie et pathogénie des maladies infectieuses. Paris: Octave Doin, 1905.

31. Loefller F (1884) Untersuchungen über die Bedeutung der Mikroorganismen für die Entstehung der Diphtherie beim Menschen: bei der Taube und beim Kalbe. Mitteil Kaiser Gesundheit 2:421-499

32. Roux E, Yersin A (1888) Contribution à l'étude de la diphtérie (partie 1). Ann Instit Pasteur 2:629-661

33. Chomel JBL (1749) Huitième malade. In: Chomel JBL (ed) Dissertation historique sur l'espèce de mal de gorge gangréneux qui a regné parmi les enfans l'année dernière. Desprez and Cavelier, Paris, pp 27-35

34. Orillard A (1837) Mémoire sur l'épidémie d'angine couenneuse qui a régné pendant le cours des années 1834,1835 et 1836, dans plusieurs communes du département de la Vienne. Bull Soc Med Poitiers 2:1-112

35. Charcot JM, Vulpian A (1862) Note sur l'état des muscles et des nerfs du voile du palais dans un cas d'angine diphthéritique. C R Soc Biol 14:173-176

36. Leyden E (1870) Ueber Reflexlähmungen. Samml Klin Vort $1: 1-22$

37. Dejerine $\mathbf{J}$ (1878) Recherches sur les lésions du système nerveux dans la paralysie diphthéritique. Arch Physiol Norm Pathol 5:107-143

38. Sharma NC, Efstratiou A, Mokrousov I, Mutreja A, Das B, Ramamurthy T (2019) Diphtheria. Nat Rev Dis Primers 5:81

39. Mathis S, Soulages A, Le Masson G, Vallat JM (2020) History of acute polyradiculoneuropathy (part 2): from 1916 to nowadays. Neurology 94:836-840

40. Mathis S, Soulages A, Vallat JM, Le Masson G (2020) History of acute polyradiculoneuropathy (part 1): the prehistory of GuillainBarré syndrome. Neurology 94:828-835

41. Webber SG (1884) Multiple neuritis. Arch Med 10:33-49

42. Holmes G (1917) Acute febrile polyneuritis. Br Med J 2:37-39

43. Cruchet R, Moutier J, Calmettes A (1917) Quarante cas d'encéphalomyélite subaiguë. Bull Soc Med Hop Paris 41:614-616

44. Economo C (1917) Encephalitis lethargica. Wiener Klin Wochen 30:581-585

45. Reid AH, McCall S, Henry JM, Taubenberger JK (2001) Experimenting on the past: the enigma of von Economo's encephalitis lethargica. J Neuropathol Exp Neurol 60:663-670

46. Bériel L, Devic A (1925) Les formes "périphériques" de l'encéphalite limbique. Presse Med 33:1141-1142

47. Paliard F, Dechaume J (1931) Forme périphérique de l'encéphalite épidémique ou polynévrite infectieuse primitive. Les septinévrites à ultra-virus neurotrope schwannophiles. Lyon Med 148:173-183

48. Sabin AB, Aring CD (1941) Visceral lesions in infectious polyneuritis (infectious neuronitis, acute polyneuritis with facial diplegia, Guillain-Barré syndrome, Landry's paralysis). Am J Pathol 17:469-481

49. Waksman BH, Adams RD (1955) Allergic neuritis: an experimental disease of rabbits induced by the injection of peripheral nervous tissue and adjuvants. J Exp Med 102:213-236

50. Asbury AK, Arnason BG, Adams RD (1969) The inflammatory lesion in idiopathic polyneuritis. Its role in pathogenesis. Med (Baltim) 48:173-215

51 Ramos-Alvarez M, Bessudo L, Sabin AB (1969) Paralytic syndromes associated with noninflammatory cytoplasmic or nuclear neuronopathy: Acute paralytic disease in Mexican children, neuropathologically distinguishable from LandryGuillain-Barré syndrome. JAMA 207:1481-1492

52. Sliman NA (1978) Outbreak of Guillain-Barré syndrome associated with water pollution. Br Med J 1:751-752

53. McKhann GM, Cornblath DR, Ho T et al (1991) Clinical and electrophysiological aspects of acute paralytic disease of children and young adults in northern China. Lancet 338:593-597

54. Yuki N, Hartung HP (2012) Guillain-Barré syndrome. N Engl J Med 366:2294-2304

55. Watrin L, Ghawché F, Larre P, Neau JP, Mathis S, Fournier E (2016) Guillain-Barré syndrome (42 Cases) occurring during a Zika virus outbreak in French Polynesia. Med (Baltim) 95:e3257

56. Capasso A, Ompad DC, Vieira DL, Wilder-Smith A, Tozan Y (2019) Incidence of Guillain-Barré Syndrome (GBS) in Latin America and the Caribbean before and during the 2015-2016 Zika virus epidemic: a systematic review and meta-analysis. PLoS Negl Trop Dis 13:e0007622

57. Piontkivska H, Plonski NM, Miyamoto MM, Wayne ML (2019) Explaining pathogenicity of congenital Zika and Guillain-Barré syndromes: does dysregulation of RNA editing play a role? BioEssays 41:e1800239

58 Diaz-Soto S, Chavez K, Chaca A, Alanya J, Tirado-Hurtado I (2019) Outbreak of Guillain-Barré syndrome in Peru. eNeurological Sci 14:89-90

59. Lima MES, Bachur TPR, Aragao GF (2019) Guillain-Barré syndrome and its correlation with dengue, Zika and chikungunya viruses infection based on a literature review of reported cases in Brazil. Acta Trop 197:105064

60. Finsterer J, Scorza FA, Ghosh R (2020) COVID-19 polyradiculitis in 24 patients without SARS-CoV-2 in the cerebro-spinal fluid. $\mathrm{J}$ Med Virol. https://doi.org/10.1002/jmv.26121

61. Centers for Disease Control and Prevention (2008) Investigation of progressive inflammatory neuropathy among swine slaughterhouse workers-Minnesota, 2007-2008. MMWR Morb Mortal Wkly Rep 57:122-124

62. Lachance DH, Lennon VA, Pittock SJ et al (2010) An outbreak of neurological autoimmunity with polyradiculoneuropathy in workers exposed to aerosolised porcine neural tissue: a descriptive study. Lancet Neurol 9:55-66

63. Holzbauer SM, DeVries AS, Sejvar JJ et al (2010) Epidemiologic investigation of immune-mediated polyradiculoneuropathy among abattoir workers exposed to porcine brain. PLoS ONE 5:e9782

64. Muley SA, Holzbauer S, Clark B et al (2018) Immunohistochemistry and electrophysiological findings in swine abattoir workers with immune-mediated polyradiculoneuropathy. J Neurol Sci 385:34-38

65. Ghaderi S, Gunnes N, Bakken IJ, Magnus P, Trogstad L, Haberg SE (2016) Risk of Guillain-Barré syndrome after exposure to pandemic influenza $\mathrm{A}(\mathrm{H} 1 \mathrm{~N} 1) \mathrm{pdm} 09$ vaccination or infection: a Norwegian population-based cohort study. Eur J Epidemiol 31:67-72

66. Schonberger LB, Hurwitz ES, Katona P, Holman RC, Bregman DJ (1981) Guillain-Barré syndrome: its epidemiology and associations with influenza vaccination. Ann Neurol 9(Suppl):31-38

67. Dudley MZ, Halsey NA, Omer SB et al (2020) The state of vaccine safety science: systematic reviews of the evidence. Lancet Infect Dis 20:e80-e89

68. German Advisory Committee Blood (Arbeitskreis Blut) (2016) Subgroup 'assessment of pathogens transmissible by blood'. Human Immunodeficiency Virus (HIV). Transfus Med Hemother 43:203-222.

69. Centner CM, Bateman KJ, Heckmann JM (2013) Manifestations of HIV infection in the peripheral nervous system. Lancet Neurol 12:295-309

70. Kean WF, Tocchio S, Kean M, Rainsford KD (2013) The musculoskeletal abnormalities of the Similaun Iceman ("OTZI"): clues 
to chronic pain and possible treatments. Inflammopharmacology 21:11-20

71. McKay MM (1980) The Rev. Dr. John Walker's report on the hebrides of 1764 and 1771. J. Donald, Edinburgh

72. Afzelius A (1910) Verhandlungen der dermatologischen Gesellschaft zu Stockholm. Arch Dermatol Syphilis 101:403-404

73. Afzelius A (1921) Erythema chronicum migrans. Acta Dermatol Venerol 2:120-125

74. Steere AC, Malawista SE, Snydman DR, Andiman WA (1976) A cluster of arthritis in children and adults in Lyme, Connecticut. Chicago, Illinois (1976, June 10-11). In: Proceedings of the 40th Annual Scientific Session of the American Rheumatism Association, 1976.
75. Burgdorfer W, Barbour AG, Hayes SF, Benach JL, Grunwaldt E, Davis JP (1982) Lyme disease-a tick-borne spirochetosis? Science 216:1317-1319

76. Paules CI, Marston HD, Bloom ME, Fauci AS (2018) Tickborne-confronting a growing threat. N Engl J Med 379:701-703

77. Summer G, Rupprecht TA (2019) Neurologic manifestations of Lyme Borreliosis. Rev Neurol (Paris) 175:417-419

78. Garin C, Bujadoux C (1922) Paralysie par les tiques. J Med Lyon 71:765-767

79. Vallat JM, Hugon J, Lubeau M, Leboutet MJ, Dumas M, Desproges-Gotteron R (1987) Tick-bite meningoradiculoneuritis: clinical, electrophysiologic, and histologic findings in 10 cases. Neurology 37:749-753 